\title{
Prolonged erythrocyte T-polyagglutination in two children with bowel disorders
}

\author{
DAISY OBEID, G. W. G. BIRD, AND JUNE WINGHAM \\ From the West Midlands Regional Blood Transfusion Service, Vincent Drive, Edgbaston, Birmingham \\ B15 2SG, UK
}

SUMMARY In vivo erythrocyte polyagglutination of microbial origin is usually a transient condition. In two children with bowel disorders, erythrocyte $T$-polyagglutination persisted for 12 months in one case and for seven months in the other. Both children required blood transfusions to support surgery. Washed red cell concentrates were transfused instead of whole blood to prevent dangerous destruction of T-transformed erythrocytes by anti-T antibodies normally present in the plasma of blood donors.

Interest in erythrocyte polyagglutination, a source of error in blood grouping, has greatly increased in recent years. There are various forms of erythrocyte polyagglutination (Table 1): some are due to the action of bacterial or viral enzymes on the erythrocyte surface. In T-polyagglutination, the enzyme responsible is neuraminidase, which is produced by some viruses and many bacteria (Gottschalk, 1957; Müller, 1974): Tk-polyagglutination is caused by an unidentified enzyme produced by some strains of Bacteroides fragilis (Inglis et al., 1975). For in vivo polyagglutination to occur, bacteria need not be in the blood stream; their enzymes may enter the blood stream by absorption from either an infected focus or a disordered gut (or lung) (Bird, 1977): more enzyme than is required to neutralise enzyme-inhibitors normally present in human plasma must enter the blood stream.

T- and Tk-polyagglutination are similar but not identical. In both forms, the red cells are agglutinated by a lectin obtained from peanuts, Arachis hypogaea (Bird, 1964; Bird and Wingham, 1972). However, Tand Tk-polyagglutination can be distinguished by application of the scheme given in Table 2 .

Children with erythrocyte polyagglutination associated with bowel disorders (Bird and Stephenson, 1973) or respiratory infections (Rickard et al., 1969) have been reported. The child described by Bird and Stephenson (1973) had intestinal obstruction and transient erythrocyte polyagglutination which was stated to be due to T-transformation; no mention was made, however, of the exclusion of Tk. Since it

Received for publication 23 March 1977

\section{Table 1 Classification of erythrocyte polyagglutination}

\begin{tabular}{lc}
\hline Microbial & $\begin{array}{c}\text { Acquired forms of erythrocyte polyagglutination } \\
\text { i Passive adsorption of bacterial products by } \\
\text { red cells }\end{array}$ \\
ii Enzymic-T, Tk, acquired B, VA \\
Non-microbial & Tn \\
& $\begin{array}{l}\text { Inherited forms of erythrocyte polyagglutination: } \\
\text { Strongest form of Cad (Super Sd }\end{array}$ \\
& HEMPAS \\
\hline
\end{tabular}

Table 2 Differences between $T$ - and $T k$ polyagglutination

\begin{tabular}{lll}
\hline & $T$ & $T k$ \\
\hline Sialic acid level & Reduced & Normal \\
Aggregation by polybrene & - & + \\
Agglutination by peanut lectin & + & + \\
Agglutination by soya bean lectin & + & - \\
Agglutination by BS II lectin* & - & + \\
AB serum after absorption of anti-T & - & + \\
AB serum after absorption of anti-Tk & + & - \\
Effect of ficin on receptor & Damaged & Enhanced \\
\hline
\end{tabular}

*A second lectin isolated from the seeds of Bandeiraea simplicifolia (Judd et al., 1975): test in albumin at $4^{\circ}$.

has been observed by two of us (GWGB and JW) that a prolonged form of $T$-polyagglutination is sometimes seen in children with bowel disorders, we thought it might be useful to describe two recent examples.

\section{Case reports}

CASE 1

A 22-day-old boy was admitted to hospital because of failure to thrive. On the day after birth he had 
abdominal distension and vomiting, and he had passed no faeces since delivery. A simple abdominal $x$-ray confirmed the diagnosis of intestinal obstruction. An enema released a small plug of meconium. He remained constipated until he was admitted to hospital. Rectal biopsy established a diagnosis of Hirschsprung's disease with non-specific colitis. Blood grouping showed that he was group $A B$, Rhesus positive, whereas his mother's group was $\mathrm{O}$, Rhesus positive. Investigation of this anomaly showed that the baby's cells were polyagglutinable and that they were strongly agglutinated by peanut and soya-bean extracts and not aggregated by polybrene. More elaborate tests (absorption, sialic acid estimation, etc) confirmed that they were $T$ - and not Tk- polyagglutinable. There was no evidence of haemolytic anaemia. Blood culture was sterile. Urine examination showed the presence of staphylococci$1000 / \mathrm{ml}$; Escherichia coli-1000/ml; and Streptococcus faecalis-10 000/ml: these numbers are probably of no significance.

Since his $\mathrm{Hb}$ was $7 \mathrm{~g} / \mathrm{dl}$ he was transfused with 100 $\mathrm{ml}$ of group $\mathrm{O}$, Rhesus positive, washed red cell concentrate before a left iliac colostomy was done. Washed red cell concentrate was given instead of whole blood because most human adult plasma contains anti-T.

\section{CASE 2}

A 16-day-old boy was admitted to hospital because of continual vomiting. On the sixth day after birth he vomited bile, and on the 10th day there was melaena. He continued to vomit bile and had 'offensive' and bloody stools. On admission a simple abdominal $x$-ray suggested malrotation of the mid-gut. The baby (group A, Rhesus positive) was transfused with $\mathbf{3 0}$ $\mathrm{ml}$ of group A, Rhesus positive red cell concentrate. At laparotomy volvulus neonatorum was found and corrected. There was some doubt about the viability of the small bowel but no resection was done at this stage. On the fourth day after operation the baby's condition deteriorated, and a second laparotomy was performed. Most of the small intestine was found to be infarcted and was resected. E. coli 099 was isolated from the peritoneal fluid. Blood culture was sterile. A week later a second blood transfusion was needed. The blood group at this stage appeared to be AB, Rhesus positive. This anomaly was investigated and found to be caused by T-polyagglutination by the methods used for case 1 . The baby was transfused with $30 \mathrm{ml}$ of group A, Rhesus positive washed red cell concentrate without any ill-effects.

\section{Discussion}

Since each patient had a gut disorder, it is reasonable to assume that the inflamed bowel permitted the transfer of enough bacterial neuraminidase to the blood stream to cause T-polyagglutinability. There was no haemolytic anaemia in either case, which is not surprising since anti-T is not present in the sera of young children. Neither patient suffered any jlleffects from transfusion of red cell concentrate, whereas the infant reported by Van Loghem et al. (1955) had a fatal reaction, and the child described by Bird and Stephenson (1973) a severe reaction, after the transfusion of whole blood, the plasma of which contained anti- $T$ antibodies.

Polyagglutinability disappeared after 12 months in case 1 and after seven months in case 2. Microbial polyagglutination is usually transient; however, the two patients described in this report showed that T-polyagglutination associated with bowel disorders in children may persist for months.

In conclusion, we must emphasise that all blood group AB findings in very young babies should be carefully checked to exclude erythrocyte polyagglutination as a source of error. The necessity for this precaution in blood grouping in connexion with blood transfusion or paternity testing should be obvious.

We thank Mr J. J. Corkery for permission to study these two patients.

\section{References}

Bird, G. W. G. (1964). Anti-T in peanuts. Vox Sanguinis, 9, 748-749.

Bird, G. W. G. (1977). Complexity of erythrocyte polyagglutinability. In Human Blood Groups. Proceedings of the 5th International Convocation on Immunology, Grand Island, N.Y. S. Karger, Basel. (In press.)

Bird, T., and Stephenson, J. (1973). Acute haemolytic anaemia associated with polyagglutinability of red cells. Journal of Clinical Pathology, 26, 868-870.

Bird, G. W. G., and Wingham, J. (1972). Tk: a new form of red cell polyagglutination. British Journal of Haematology, 23, 759-763.

Gottschalk, A. (1957). Neuraminidase: the specific enzyme of influenza virus and Vibrio cholerae. Biochimica et Biophysica Acta, 23, 645-646.

Inglis, G., Bird, G. W. G., Mitchell, A. A. B., Milne, G. R., and Wingham, J. (1975). Effect of Bacteroides fragilis on the human erythrocyte membrane: pathogenesis of Tk polyagglutination. Journal of Clinical Pathology, 28, 964-968.

Judd, W. J., Shankar, R. N., Goldstein, I. J., Beck, M. L., and Hicklin, B. L. (1975). Further haemagglutinating activity in Bandeiraea simplicifolia seeds with specificity for 'acquired-B' red cells (Abstract). Programme 28th Annual Meeting of the American Association of Blood Banks, Chicago, p. 109.

Müller, H. E. (1974). Neuraminidase of mycoplasma, bacteria and protozoa. Behring Institute Mitteilungen, 55, 34-56. 
Rickard, K. A., Robinson, R. J., and Worlledge, S. M. (1969). Acute acquired haemolytic anaemia associated with polyagglutination. Archives of Disease in Childhood, 44, 102-105.
Van Loghem, J. J., Jr., van der Hart, M., and Land, M.E. (1955). Polyagglutinability of red cells as a cause of a severe haemolytic transfusion reaction. Vox Sanguinis (Old Series), 5, 125-128.

\section{Reports and Bulletins prepared by the Association of Clinical Biochemists}

The following reports and bulletins are published by the Association of Clinical Biochemists. They may be obtained from The Publishing Department, British Medical Journal (ACB Technical Bulletins), B.M.A. House, Tavistock Square, London WC1H 9JR. Overseas readers should remit by British Postal or Money Order.

SCIENTIFIC REPORTS (price $£ 1 \cdot 00 / \$ 2.00$ each)

3 Automatic dispensing pipettes: an assessment of 35 commercial instruments September 1967 P. M. G. BROUGHTON, A. H. GOWENLOCK, G. M. WIDDOWSON, and K. A. AHLQUIST

4 An evaluation of five commercial flame photometers suitable for the simultaneous determination of sodium and potassium March 1970 P. M. G. BROUGHTON and J. B. DAWSON

SCIENTIFIC REVIEWS (price $£ 1 \cdot 00 / \$ 2.00$ each)

1 The assessment of thyroid function March 1971 F. V. FLYNN and J. R. HOBBS

2 Renal function tests suitable for clinical practice January 1972 F. L. MITCHELL, N. VEALL, and R. W. E. WATTS

3 Biochemical tests for the assessment of fetoplacental function May 1975 C. E. WILDE and R. E. OAKEY

4 Test of exocrine pancreatic function March 1977 A. H. GOWENLOCK

TECHNICAL BULLETINS (price $£ 1 \cdot 00 / \$ 2.00$ each)

9 Determination of urea by AutoAnalyzer November 1966 RUTH M. HASLAM

11 Determination of serum albumin by AutoAnalyzer using bromocresol green October 1967 B. E. NORTHAM and G. M. WIDDOWSON

13 An assessment of the Technicon Type II Sampler Unit March 1968 B. C. GRAY and G. K. MCGOWAN

14 Atomic absorption spectroscopy: an outline of its principles and a guide to the selection of instruments May 1968 J. B. DAWSON and P. M. G. BROUGHTON

15 A guide to automatic pipettes (2nd edition) June 1968 P. M. G. BROUGHTON

16 A guide to automation in clinical chemistry May 1969 P. M. G. BROUGHTON

17 Flame photometers: a comparative list of 17 instruments readily available in Britain August 1969 P. WILDING

19 Spectrophotometers: a comparative list of low-priced instruments readily available in Britain May 1970 C. E. WILDE and P. SEWELL

20 Quantities and units in clinical biochemistry June 1970 P. M. G. BROUGHTON
21 Filter fluorimeters: A comparative list of 18 instruments September 1970 H. BRAUNSBERG and S. S. BROWN

22 Bilirubin standards and the determination of bilirubin by manual and technicon AutoAnalyzer methods January 1971 BARBARA BILLING, RUTH HASLAM, and $\mathrm{N}$. WALD

23 Interchangeable cells for spectrophotometers and fluorimeters September 1971 S. S. BROWN and A. H. GOWENLOCK

24 Simple tests to detect poisons March 1972 B. W. MEADE et al.

25 Blood gas analysers May 1972 K. DIXON

26 Kits for enzyme activity determination September 1972 S. B. ROSALKI and D. TARLOW

27 Assessment of pumps suitable for incorporation into existing continuous flow analytical systems November 1972 A. FLECK et al.

28 Routine clinical measurements of transferrin in human serum September 1973 K. DIXON

29 Control materials for clinical biochemistry (5th edition) September 1973 J. F. STEVENS

30 Notes on the quality of performance of serum cholesterol assays September 1973 s. S. BROWN

31 Determination of uric acid in blood and in urine July 1974 R. W. E. WATTS

32 A survey of amino acid analysers readily available in the United Kingdom September 1974 J. E. CARLYLE and P. PURKISS

33 Definitions of some words and terms used in automated analysis November 1974 A. FLECK, R. ROBINSON, S. S. BROWN, and J. R. HOBBS

34 Measurement of albumin in the sera of patients January 1975 LINDA SLATER, P. M. CARTER, and J. R. HOBBS

35 Investigation of the validity of temperature correction factors for serum aspartate and alanine transaminases March 1975 s. B. ROSALKI et al.

36 Factors influencing the assay of creatinine November 1975 J. G. H. COOK

37 A survey of enzyme reaction rate analysers readily available in the United Kingdom July 1977 R. A. SAUNDERS and R. F. BURNS 